\title{
Advantages of an Electrochemical Method Compared to the Spectrophotometric Kinetic Study of Peroxidase Inhibition by Boroxine Derivative
}

\author{
Jelena Ostojić ${ }^{1, *}$ (D), Safija Herenda ${ }^{1}$, Zerina Bešić ${ }^{1}$, Mladen Miloš ${ }^{2}$ and Borivoj Galić ${ }^{1}$ \\ 1 Department of Chemistry, Faculty of Science, University of Sarajevo, Zmaja od Bosne 33-35, \\ 71000 Sarajevo, Bosnia and Herzegovina; islamovic.safija@gmail.com (S.H.); zerinaa93@hotmail.com (Z.B.); \\ borivoj.galic@gmail.com (B.G.) \\ 2 Faculty of Chemistry and Technology, University of Split, Teslina 10, 21000 Split, Croatia; milos@ktf-split.hr \\ * Correspondence: ostojic.jelena@live.com; Tel.: +387-6178-9487
}

Received: 29 May 2017; Accepted: 3 July 2017; Published: 5 July 2017

\begin{abstract}
In this study, boroxine derivative $\left(\mathrm{K}_{2}\left[\mathrm{~B}_{3} \mathrm{O}_{3} \mathrm{~F}_{4} \mathrm{OH}\right]\right)$ was tested as an inhibitor of horseradish peroxidase (HRP) by spectrophotometric and electrochemical methods. The activity of horseradish peroxidase was first studied under steady-state kinetic conditions by a spectrophotometric method which required the use of guaiacol as a second substrate to measure guaiacol peroxidation. The results of this method have shown that, by changing the concentration of guaiacol as the literature suggests, a different type of inhibition is observed than when changing the concentration of hydrogen peroxide as the substrate. This suggests that guaiacol interferes with the reaction in some way. The electrochemical method involves direct electron transfer of HRP immobilized in Nafion nanocomposite films on a glassy carbon (GC) electrode, creating a sensor with an electro-catalytic response to the reduction of hydrogen peroxide. The electrochemical method simplifies kinetic assays by removing the requirement of reducing substrates.
\end{abstract}

Keywords: boroxine derivative; peroxidase; enzyme kinetics; cyclic voltammetry

\section{Introduction}

The boroxine derivative, dipotassium-trioxohydroxytetrafluorotriborate $\mathrm{K}_{2}\left[\mathrm{~B}_{3} \mathrm{O}_{3} \mathrm{~F}_{4} \mathrm{OH}\right]$, has lately been intensively studied as a potential enzyme inhibitor. $\mathrm{K}_{2}\left[\mathrm{~B}_{3} \mathrm{O}_{3} \mathrm{~F}_{4} \mathrm{OH}\right]$ has been shown to be an effective inhibitor of catalase and some human carbonic anhydrases [1,2]. Most recent research has investigated $\mathrm{K}_{2}\left[\mathrm{~B}_{3} \mathrm{O}_{3} \mathrm{~F}_{4} \mathrm{OH}\right]$ as an inhibitor of horseradish peroxidase (HRP) and has found that $\mathrm{K}_{2}\left[\mathrm{~B}_{3} \mathrm{O}_{3} \mathrm{~F}_{4} \mathrm{OH}\right]$ binds to the native HRP enzyme, showing an example of competitive inhibition [3].

Horseradish peroxidase is an important heme-containing enzyme and is widely used for analytical purposes, biosensors and enzymatic bioreactors [4-6].

The detection of HRP activity is widely used in labelling systems and a large number of procedures for monitoring its reaction have been developed. To monitor HRP activity, substances often referred to as peroxidase substrates need to be added to the reaction mixture. These substrates are electron donors and, when oxidized by HRP with hydrogen peroxide present as the oxidizing agent, a characteristic change that is detectable by the spectrophotometric method takes place $[7,8]$. The most common substrate used as an electron donor is guaiacol; it was therefore also used in this research. A spectrophotometric assay of peroxidase activity using guaiacol is a common analytical method for quantifying enzymatic activity based on the change in absorbance at $470 \mathrm{~nm}$. The formed product, tetraguaiacol, is amber-colored and is detectable by a UV/VIS spectrophotometer [9-13].

Nowadays, there is also an increasing trend in making biosensors which include immobilized HRP for the removal of hydrogen peroxide. The activity of HRP when immobilized can be monitored using 
chronoamperometry and cyclic voltammetry can be used for the characterization of the immobilized enzyme. Electrochemical techniques have their advantages because of their simplicity, low cost and speed. The only condition for this method of monitoring enzyme kinetics is that direct electron transfer must be possible or able to be achieved by mediators [14-18]. Efficient electron transfer is difficult to achieve in many cases because the active site of an enzyme can be trapped deep inside the enzyme structure, as well as because denaturation of the enzyme can easily occur during the process of immobilization. Direct electron transfer of HRP has been reported in many papers using many carriers: for example, sol-gel matrices, biopolymers, and nanomaterials [19-23]. Many enzymes including HRP have been immobilized using a Nafion matrix because it does not show any denaturalization of enzymes or their enzymatic activity.

Direct electron transfer of immobilized HRP is based on the $\mathrm{Fe}(\mathrm{III}) / \mathrm{Fe}(\mathrm{II})$ reduction in the active heme center of the enzyme.

When $\mathrm{H}_{2} \mathrm{O}_{2}$ is involved, the reaction mechanism is a little more complex. HRP reacts with $\mathrm{H}_{2} \mathrm{O}_{2}$ and forms an oxidized form of the enzyme called Compound I $\left(\mathrm{HRP}\left(\mathrm{Fe}^{+4}=\mathrm{O}\right)^{+}\right)$, which is actually an intermediate. Compound I contains oxyferryl heme $\left(\mathrm{Fe}^{+4}=\mathrm{O}\right)$ and a porphyrin $\pi$ cation radical. Compound I is also catalytically active and, when receiving one electron from the substrate, converts to Compound II $\left(\mathrm{HRP}\left(\mathrm{Fe}^{+4}=\mathrm{O}\right)\right)$. Compound II also contains an $\mathrm{Fe}(\mathrm{IV})$ oxyferryl species that is one oxidizing equivalent above the resting state. The catalytic mechanism is shown below in steps:

$$
\begin{gathered}
\operatorname{HRP}(\mathrm{Fe}-\mathrm{III})+\mathrm{H}_{2} \mathrm{O}_{2} \rightarrow \operatorname{HRP}\left(\mathrm{Fe}^{+4}=\mathrm{O}\right)^{+}+\mathrm{H}_{2} \mathrm{O}\left(\mathrm{k}_{1}\right) \\
\operatorname{HRP}\left(\mathrm{Fe}^{+4}=\mathrm{O}\right)^{+}+\mathrm{AH}_{2} \rightarrow \operatorname{HRP}\left(\mathrm{Fe}^{+4}=\mathrm{O}\right)+\mathrm{AH} \cdot\left(\mathrm{k}_{2}\right) \\
\mathrm{HRP}\left(\mathrm{Fe}^{+4}=\mathrm{O}\right)+\mathrm{AH}_{2} \rightarrow \operatorname{HRP}(\mathrm{Fe}-\mathrm{III})+\mathrm{AH}+\mathrm{H}_{2} \mathrm{O}\left(\mathrm{k}_{3}\right) \\
\mathrm{AH} \cdot+\mathrm{e}^{-}+\mathrm{H}^{+} \rightarrow \mathrm{AH}_{2}+\mathrm{H}_{2} \mathrm{O}\left(\mathrm{k}_{4}\right)
\end{gathered}
$$

where HRP (Fe-III) is the native enzyme, sometimes referred as the resting enzyme, $\mathrm{HRP}\left(\mathrm{Fe}^{+4}=\mathrm{O}\right)^{+}$ and HRP $\left(\mathrm{Fe}^{+4}=\mathrm{O}\right)$ are the oxidized forms of the enzyme and $\mathrm{AH}_{2}$ and $\mathrm{AH} \cdot$ are the electron donor substrate and the radical product of its one-electron oxidation [24].

The enzyme immobilized on an electrode when hydrogen peroxide is present is being oxidized and converted to Compound I, as shown in reaction (1). Compound I is further reduced by electrons provided from an electrode, reaction (5):

$$
\operatorname{HRP}\left(\mathrm{Fe}^{+4}=\mathrm{O}\right)^{+}+2 \mathrm{e}^{-}+2 \mathrm{H}^{+} \rightarrow \operatorname{HRP}(\mathrm{Fe}-\mathrm{III})+\mathrm{H}_{2} \mathrm{O}\left(\mathrm{k}_{\mathrm{s}}\right)
$$

Electron donors $\left(\mathrm{AH}_{2}\right.$ from reaction 2 and 3$)$ are unnecessary, because the electrode provides both electrons and the enzyme is converted in its resting state.

An electron donor can also be present in a peroxidase-electrode system; both processes can then occur at the same time and the oxidized donor $\mathrm{AH}$ - is then electrochemically reduced by an electrode, as shown in reaction (4). The other case is known as a mediated electron transfer, which is sometimes more efficient than direct electron transfer.

The purpose of this paper is to show that the electrochemical method has advantages over the spectrophotometric method; mostly because of the ease of conducting experimental work. The other reason is that most literature recommends the use of guaiacol for spectrophotometric measurements; not only to be present in the reaction system, but also to use it when changing the concentration of the substrate, because it avoids increasing $\mathrm{H}_{2} \mathrm{O}_{2}$ concentration to prevent the inactivation of the enzyme. For that reason, we conducted the same experiments and untypical behavior of our inhibitor was shown. Furthermore, the goal of our research was to compare two methods and to show that, when using the spectrophotometric method, electron donors such as guaiacol could interfere with the inhibitor $\mathrm{K}_{2}\left[\mathrm{~B}_{3} \mathrm{O}_{3} \mathrm{~F}_{4} \mathrm{OH}\right]$ and cause problems when determining the type of inhibition. 


\section{Results}

\subsection{Determination of $K_{m}$ and $V_{\max }$-Spectrophotometric Method}

For kinetic measurements using the spectrophotometric method with no inhibitor present, the kinetic constants calculated were: $K_{m}=0.47 \mathrm{mM}$ and $V_{\max }=0.34 \mathrm{mM} \mathrm{min}^{-1}$ when guaiacol was only present in a fixed concentration $(1.33 \mathrm{mM})$ and where plots were gained as a function of concentration of $\mathrm{H}_{2} \mathrm{O}_{2}$.

When an inhibitor was present, the same kinetic measurements were performed and, using a double reciprocal graph, the calculated value of $\mathrm{V}_{\max }$ was $0.34 \mathrm{mM} \mathrm{min}^{-1}$, but $\mathrm{K}_{\mathrm{m}}$ values were different for each concentration of $\mathrm{K}_{2}\left[\mathrm{~B}_{3} \mathrm{O}_{3} \mathrm{~F}_{4} \mathrm{OH}\right]$. $\mathrm{Km}$ values were 1.35, 1.76, 2.92, 6.48 and $7.85 \mathrm{mM}$ with respect to the concentration of $\mathrm{K}_{2}\left[\mathrm{~B}_{3} \mathrm{O}_{3} \mathrm{~F}_{4} \mathrm{OH}\right]$ (Figure 1).

For kinetic measurements when $\mathrm{H}_{2} \mathrm{O}_{2}$ concentration was kept fixed $(0.32 \mathrm{mM})$, Lineweaver-Burk plots were gained as a function of guaiacol concentration; the calculated kinetic constants were: $\mathrm{K}_{\mathrm{m}}=3.87 \mathrm{mM}, \mathrm{V}_{\max }=0.57 \mathrm{mM} \mathrm{min}^{-1}$ with no inhibitor present.

When an inhibitor was present, values of $\mathrm{K}_{\mathrm{m}}$ and $\mathrm{V}_{\max }$ were different relative to the concentration of $\mathrm{K}_{2}\left[\mathrm{~B}_{3} \mathrm{O}_{3} \mathrm{~F}_{4} \mathrm{OH}\right]$. Calculated $\mathrm{K}_{\mathrm{m}}$ values were 3.05, 2.41, 0.41, 0.17 and $0.17 \mathrm{mM}$, and from the intersection of the $y$-axis, the $\mathrm{V}_{\max }$ values were also variable: $0.49,0.38,0.10,0.03$ and $0.02 \mathrm{mM} \mathrm{min}^{-1}$ relative to the concentration of $\mathrm{K}_{2}\left[\mathrm{~B}_{3} \mathrm{O}_{3} \mathrm{~F}_{4} \mathrm{OH}\right]$ (Figure 2).

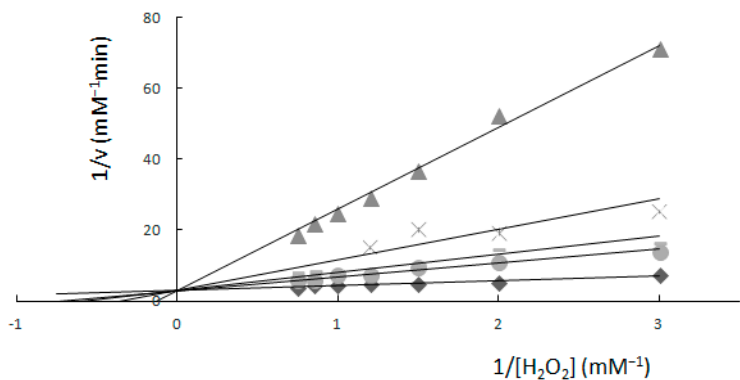

Figure 1. The graphical determination of kinetic constants from Lineweaver-Burk plots with a fixed concentration of guaiacol $(1.33 \mathrm{mM})$. Fixed concentrations of $\mathrm{K}_{2}\left[\mathrm{~B}_{3} \mathrm{O}_{3} \mathrm{~F}_{4} \mathrm{OH}\right]$ were: $(\diamond) 0.0 \mathrm{mM}$, $(\bigcirc) 4 \mathrm{mM},(-) 6 \mathrm{mM},(\times) 10 \mathrm{mM},(\Delta) 39.6 \mathrm{mM}$. Results gained by the spectrophotometric method. Reprinted from reference [3].

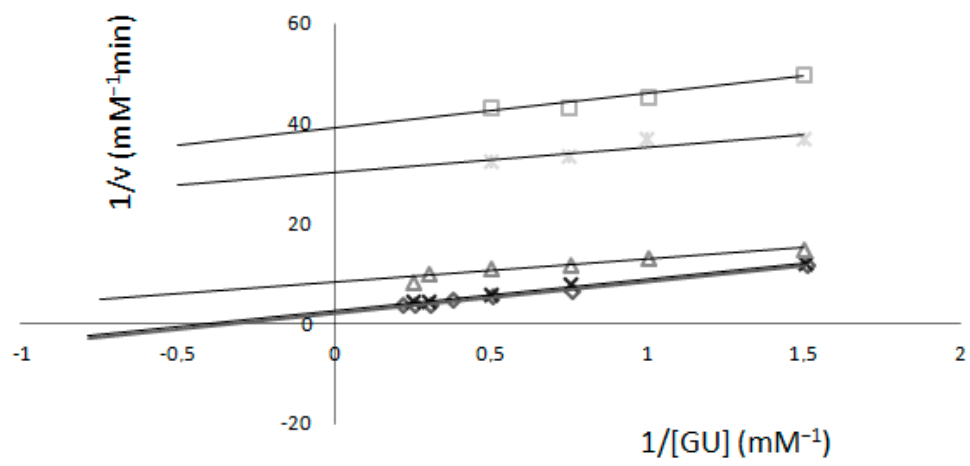

Figure 2. The graphical determination of kinetic constants from Lineweaver-Burk plots with a fixed concentration of $\mathrm{H}_{2} \mathrm{O}_{2}(0.32 \mathrm{mM})$. Fixed concentrations of $\mathrm{K}_{2}\left[\mathrm{~B}_{3} \mathrm{O}_{3} \mathrm{~F}_{4} \mathrm{OH}\right]$ were: $(\diamond) 0.0 \mathrm{mM},(\times) 0.3 \mathrm{mM}$, $(\Delta) 2.0 \mathrm{mM}$, (Ж) $4.00 \mathrm{mM},(\square) 6.0 \mathrm{mM}$. Results gained by the spectrophotometric method.

\subsection{Determination of $K_{m}$ and $I_{m a x}$ Electrochemical Method}

As mentioned before, electrochemical measurements need no involvement from the electron donor substrate, yet it can be used in the reaction system, which then becomes a mediated electron 
transfer. Curve b (Figure 3) shows the cyclic voltammogram of a GC electrode modified only with Nafion, and curve a (Figure 3) shows the cyclic voltammogram of a GC electrode modified with Nafion and enzyme (HRP) film. Cyclic voltammetry measurements were performed in $100 \mathrm{mM}$ phosphate buffer solution (PBS pH 6.0) at a scan rate of $50 \mathrm{mV} \mathrm{s}^{-1}$. Pairs of redox peaks were established at the HRP/Nafion composite film (curve a) from the electrochemical reaction between HRP-Fe(III) and HRP-Fe(II). Redox peaks were not established on the cyclic voltammogram of a GC electrode modified only with Nafion. The anodic peak potential $\left(\mathrm{E}_{\mathrm{pa}}\right)$ was observed at $0.31 \mathrm{~V}$ and the cathodic peak potential $\left(\mathrm{E}_{\mathrm{pc}}\right)$ was at $0.41 \mathrm{~V}$. This confirms that HRP film with Nafion formed on a GC electrode can perform direct electron transfer of $\mathrm{HRP}$. When $\mathrm{H}_{2} \mathrm{O}_{2}$ is added, it should react with $\mathrm{HRP}-\mathrm{Fe}(\mathrm{III})$, forming $\mathrm{O}_{2}$ and causing an increase in the current of these two reduction peaks.

Figure 4 shows the amperometric responses of both previously described electrodes upon successive additions of $\mathrm{H}_{2} \mathrm{O}_{2}$ in $100 \mathrm{mM}$ phosphate buffer ( $\mathrm{pH}$ 6.0) at an applied potential of $+0.9 \mathrm{~V}$. Amperometric curves showed that the current increases after the addition of $\mathrm{H}_{2} \mathrm{O}_{2}$ at a GC electrode with enzyme/Nafion but has almost no response at electrodes modified only with Nafion.

As is already known, the apparent Michaelis-Menten constant $\left(\mathrm{K}_{\mathrm{m}}\right)$ can be calculated from the Lineweaver-Burk equation [25]:

$$
1 / \mathrm{I}_{\mathrm{ss}}=1 / \mathrm{I}_{\max }+\mathrm{K}_{\mathrm{m}} / \mathrm{I}_{\max } 1 / \mathrm{C}
$$

$\mathrm{I}_{\mathrm{sS}}$ is the steady-state current after the addition of substrate, $\mathrm{C}$ is the bulk concentration of substrate and $\mathrm{I}_{\max }$ is the maximum current measured under saturated substrate solution.

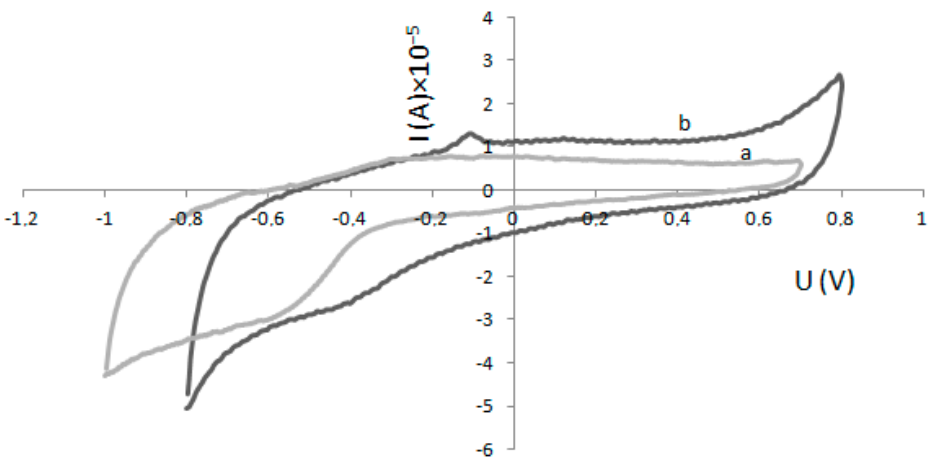

Figure 3. Cyclic voltammograms of a glassy carbon (GC) electrode modified with Nafion (curve b) and a GC electrode modified with horseradish peroxidase (HRP) and Nafion (curve a) in $100 \mathrm{mM}$ phosphate buffer solution (PBS $\mathrm{pH}$ 6.0) at a scan rate of $50 \mathrm{mV} \mathrm{s}^{-1}$.

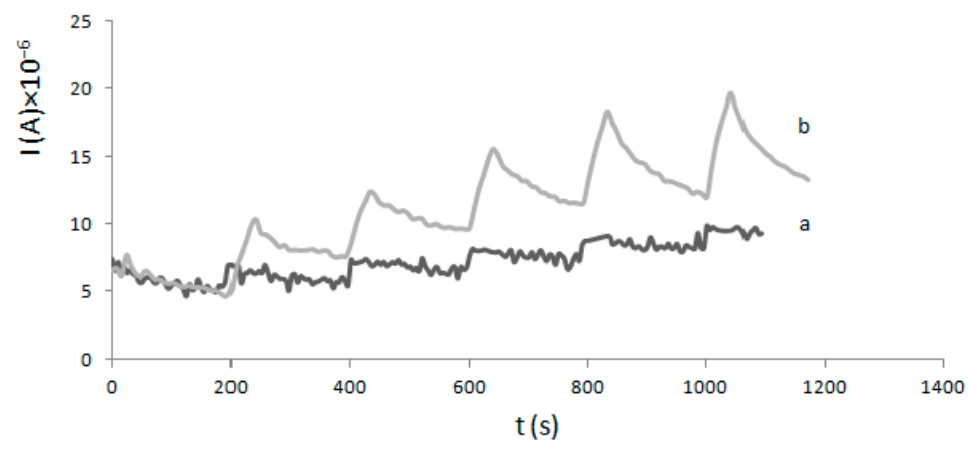

Figure 4. Amperometric responses of a GC electrode modified with HRP and Nafion (b) and a GC electrode modified only with Nafion (a) upon successive additions of $\mathrm{H}_{2} \mathrm{O}_{2}$ in $100 \mathrm{mM}$ phosphate buffer solution (PBS pH 6.0). 
The Michaelis-Menten constant $\left(\mathrm{K}_{\mathrm{m}}\right)$ is calculated from the slope and interception of the reciprocal plot of the steady-state current vs. $\mathrm{H}_{2} \mathrm{O}_{2}$ concentration.

The Michaelis-Menten constant $\left(\mathrm{K}_{\mathrm{m}}\right)$ calculated in this work in the absence of an inhibitor was $33.1 \mathrm{mM}$, suggesting that the HRP and Nafion modified glassy carbon electrode shows a lower affinity for $\mathrm{H}_{2} \mathrm{O}_{2}$ than usually reported in similar papers and also a lower affinity than for the native enzyme. The kinetic constants (e.g., $\mathrm{K}_{\mathrm{m}}, \mathrm{V}_{\max }$ ) of immobilized enzymes are usually different from the kinetic constants of free enzymes, which is most often explained by internal structural changes and confined access to the enzyme active site. This may be due to changes in the properties of the solution in the region near the immobilized enzyme or the effects of molecular diffusion within the local environment.

To determine the inhibition effect of $\mathrm{K}_{2}\left[\mathrm{~B}_{3} \mathrm{O}_{3} \mathrm{~F}_{4} \mathrm{OH}\right]$, electrochemical measurements (Figure 5) were performed at fixed concentrations of $\mathrm{K}_{2}\left[\mathrm{~B}_{3} \mathrm{O}_{3} \mathrm{~F}_{4} \mathrm{OH}\right]$ as a function of $\mathrm{H}_{2} \mathrm{O}_{2}$ concentration. From a Lineweaver-Burk plot, the calculated $\mathrm{I}_{\max }$ was $0.06 \mathrm{~mA}$. From the same plot, the calculated $\mathrm{K}_{\mathrm{m}}$ values were $33.1,48.2,63.4,89.1$ and $79.7 \mathrm{mM}$, relative to concentration of $\mathrm{K}_{2}\left[\mathrm{~B}_{3} \mathrm{O}_{3} \mathrm{~F}_{4} \mathrm{OH}\right]$.

Electrochemical measurements (Figure 6) when guaiacol was present in an electrochemical cell in a concentration of $1.33 \mathrm{mM}$ were also performed at a fixed concentration of $\mathrm{K}_{2}\left[\mathrm{~B}_{3} \mathrm{O}_{3} \mathrm{~F}_{4} \mathrm{OH}\right]$ as a function of $\mathrm{H}_{2} \mathrm{O}_{2}$ concentration. From a Lineweaver-Burk plot, a unique $\mathrm{I}_{\max }=5.4 \mathrm{~mA}$ was calculated and $\mathrm{K}_{\mathrm{m}}$ values were variable at $214.6,294.3,380.3$ and $526 \mathrm{mM}$, relative to concentration of $\mathrm{K}_{2}\left[\mathrm{~B}_{3} \mathrm{O}_{3} \mathrm{~F}_{4} \mathrm{OH}\right]$.

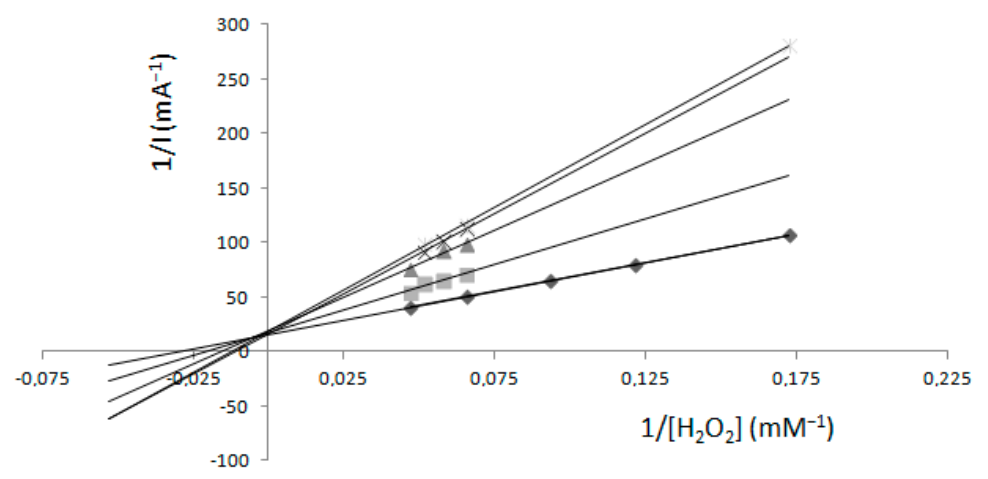

Figure 5. The graphical determination of kinetic constants from Lineweaver-Burk plots without guaiacol present. Fixed concentrations of $\mathrm{K}_{2}\left[\mathrm{~B}_{3} \mathrm{O}_{3} \mathrm{~F}_{4} \mathrm{OH}\right]$ were: $(\diamond) 0 \mathrm{mM},(\square) 2 \mathrm{mM},(\Delta) 4 \mathrm{mM}$, $(\times) 6 \mathrm{mM},($ Ж) $10 \mathrm{mM}$; Results gained by the electrochemical method.

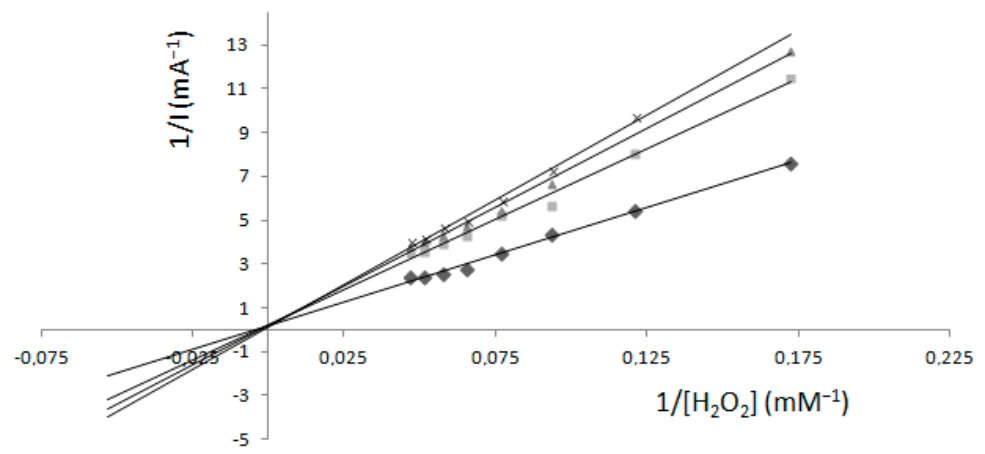

Figure 6. The graphical determination of kinetic constants from Lineweaver-Burk plots with guaiacol present in a fixed concentration of $1.33 \mathrm{mM}$. Fixed concentrations of $\mathrm{K}_{2}\left[\mathrm{~B}_{3} \mathrm{O}_{3} \mathrm{~F}_{4} \mathrm{OH}\right]$ were: $(\diamond) 0 \mathrm{mM}$, $(\square) 4 \mathrm{mM},(\Delta) 8 \mathrm{mM},(\times) 10 \mathrm{mM}$; Results gained by the electrochemical method. 


\section{Discussion}

Comparison of Two Methods

$\mathrm{K}_{2}\left[\mathrm{~B}_{3} \mathrm{O}_{3} \mathrm{~F}_{4} \mathrm{OH}\right]$ was tested as an inhibitor of HRP activity under steady-state kinetic conditions after the preincubation of the enzyme with different concentrations of $\mathrm{K}_{2}\left[\mathrm{~B}_{3} \mathrm{O}_{3} \mathrm{~F}_{4} \mathrm{OH}\right]$. Guaiacol oxidation by HRP was used to evaluate the enzymatic activity and to test the influence of the inhibitor.

The assays for guaiacol oxidation were carried out with measurements as a function of $\mathrm{H}_{2} \mathrm{O}_{2}$ concentrations and as a function of guaiacol concentrations, showing different results.

The measurements in relation to hydrogen peroxide (Figure 1) showed that values of $\mathrm{V}_{\max }$ stayed unchanged at each $\mathrm{K}_{2}\left[\mathrm{~B}_{3} \mathrm{O}_{3} \mathrm{~F}_{4} \mathrm{OH}\right]$ concentration. The effect of $\mathrm{K}_{2}\left[\mathrm{~B}_{3} \mathrm{O}_{3} \mathrm{~F}_{4} \mathrm{OH}\right]$ on $\mathrm{H}_{2} \mathrm{O}_{2}$ oxidation of guaiacol as an electron donor showed that $\mathrm{K}_{2}\left[\mathrm{~B}_{3} \mathrm{O}_{3} \mathrm{~F}_{4} \mathrm{OH}\right]$ acts as a competitive inhibitor for the enzyme. As the concentration of $\mathrm{K}_{2}\left[\mathrm{~B}_{3} \mathrm{O}_{3} \mathrm{~F}_{4} \mathrm{OH}\right]$ was increased, the apparent $\mathrm{Km}$ value also increased; the data are consistent with competitive inhibition.

The measurements in relation to guaiacol (Figure 2) showed changes in both values of $\mathrm{V}_{\max }$ and $\mathrm{K}_{\mathrm{m}}$; the data are consistent with uncompetitive inhibition suggesting that $\mathrm{K}_{2}\left[\mathrm{~B}_{3} \mathrm{O}_{3} \mathrm{~F}_{4} \mathrm{OH}\right]$ induced conformational changes and affects both peroxide sites and substrate sites.

Since the results with the spectrophotometric method were different for two forms of measurements, we performed the electrochemical method to compare the results. Electrochemical measurements were also carried out in two ways. The first form used only $\mathrm{H}_{2} \mathrm{O}_{2}$ with an immobilized electrode and, for the second, guaiacol was present in the electrochemical cell as a mediator. The electrochemical method (Figures 5 and 6) in both forms showed that values of $\mathrm{I}_{\max }$ remained unchanged at each $\mathrm{K}_{2}\left[\mathrm{~B}_{3} \mathrm{O}_{3} \mathrm{~F}_{4} \mathrm{OH}\right]$ concentration, pointing to competitive inhibition. These results agreed with spectrophotometric results in relation to $\mathrm{H}_{2} \mathrm{O}_{2}$ where the concentration of guaiacol was kept fixed.

The lower signal (mA) in the absence of guaiacol (Figure 5) and the lower $\mathrm{K}_{\mathrm{m}}$ value in comparison with measurements in the presence of $1.33 \mathrm{mM}$ guaiacol (Figure 6) is probably due to the slow electron transfer, which can be improved by adding a mediator to transfer electrons between the electrode surface and the hydrogen peroxide [26,27]. Slow electron transfer is also affected by operational parameters, such as the operating potential, mediator concentration and $\mathrm{pH}$, and thermal stability. These parameters are very important when searching for the best analytical performance when using an electrode as a sensor.

The electrochemical method proved here to be very useful to test the effect of new inhibitors. The most important aspect is that it is in correlation with the more commonly-used spectrophotometric method, yet is much simpler and requires less time to follow the enzymatic activity of horseradish peroxidase under the influence of possible inhibitors.

This study also showed that an electrochemical biosensor could be prepared without a mediator for the purpose of following enzymatic activity, regardless of the lower Km value gained. This is very important because direct electrochemical behavior of the enzyme or protein at the electrode simplifies the preparation processes of biosensors.

\section{Materials and Methods}

\subsection{Chemicals}

$\mathrm{K}_{2}\left[\mathrm{~B}_{3} \mathrm{O}_{3} \mathrm{~F}_{4} \mathrm{OH}\right]$ is a boron inorganic derivative synthesized by reacting potassium hydrofluoride $\left(\mathrm{KHF}_{2}\right)$ with boric acid, working in molar ratios of 2:3 at room temperature as reported in the literature [28]. All other compounds used were obtained as highest-purity reagents from Sigma Aldrich (Saint Louis, MO, USA) and Fisher Chemical (Waltham, MA, USA). 


\subsection{Spectrophotometric Assay of HRP Activity}

Guaiacol peroxidation was monitored spectrophotometrically by following the increase of the absorbance at $470 \mathrm{~nm}$ of the reaction mixtures within the first few minutes. The method was described by Chance and Maehly [29]. The instrument used was a MultiskanGOMicroplate spectrophotometer, Thermo Fisher Scientific, Waltham, MA, USA.

For hydrogen peroxide kinetic measurements, guaiacol concentration $(1.33 \mathrm{mM})$ was kept fixed and $\mathrm{H}_{2} \mathrm{O}_{2}$ concentration varied between 0.33 and $1.33 \mathrm{mM}$. Assays were carried out at a temperature of $25^{\circ} \mathrm{C}$. The total volume of reaction mixture was $300 \mu \mathrm{L}$, consisting of phosphate buffer at $\mathrm{pH} 6.0$ $(100 \mathrm{mM}), 25 \mu \mathrm{L}$ of enzyme solution (approximately $0.45 \mathrm{nM}$, assuming the molecular weight of HRP as $44 \mathrm{kDa}$ ) and $25 \mu \mathrm{L}$ of guaiacol. Volume of $\mathrm{H}_{2} \mathrm{O}_{2}$ was varied to make different concentrations.

When testing inhibition, the inhibitor was also present in the reaction mixture and in every experiment inhibitor was preincubated for 5 minutes with the enzyme before each measurement. The reaction was started after the addition of $\mathrm{H}_{2} \mathrm{O}_{2}$.

For guaiacol kinetic measurements, $\mathrm{H}_{2} \mathrm{O}_{2}$ concentration $(0.42 \mathrm{mM})$ was kept fixed and guaiacol concentration varied between $0.6 \mathrm{mM}$ to $4.6 \mathrm{mM}$. As in the case of kinetic measurements for hydrogen peroxide, measurements were also conducted with different concentrations of inhibitor under the same conditions. The volume of guaiacol was varied in this case to make the above-mentioned concentrations.

\subsection{Electrode Modification and Electrochemical Experiments}

Cyclic voltammetry and amperometric experiments were carried out on PAR 263A potentiostat/galvanostat and the usual three-electrode system. A saturated $\mathrm{Ag} / \mathrm{AgCl}$ electrode was employed as a reference electrode, a Pt electrode as a counter electrode and a modified glassy carbon (GC) electrode as the working electrode.

All measurements were carried out in $100 \mathrm{mM}$ pH 6.0 phosphate buffer solution (PBS) and conducted at room temperature. A magnetic stirrer (approximately $400 \mathrm{rpm}$ ) was employed during the amperometric measurements.

The electrochemical characterization of the immobilized enzyme was done by cyclic voltammetry.

Before the immobilization, the GC electrode surface was polished with $0.05 \mathrm{~mm} \mathrm{Al}_{2} \mathrm{O}_{3}$ and ultrasonically cleaned with acetone- $-\mathrm{NaOH}(1: 1), \mathrm{HNO}_{3}$ (1:1) —and rinsed with double distilled water. Then the modified electrode was left to dry at room temperature.

After cleaning the GC electrode, a volume of $10 \mu \mathrm{L}$ of a mixed solution of $0.05 \mathrm{ng} / \mathrm{mL} \mathrm{HRP}$ and $5 \%(w / w)$ Nafion was dripped on the surface of the electrode. The HRP/Nafion electrode was left to dry at room temperature for at least 90 minutes.

Amperometric measurements were carried out in the electrochemical cell containing $25 \mathrm{~mL}$ of buffer solution. The modified electrode, together with the reference and the counter electrode, was immersed into a phosphate buffer solution and the change of current was observed when $0.1 \mathrm{mM} \mathrm{H}_{2} \mathrm{O}_{2}$ was added in the mixture. A constant potential of $0.9 \mathrm{~V}$ was applied on the working electrode. The reaction was monitored in the absence and in the presence of different concentrations of $\mathrm{K}_{2}\left[\mathrm{~B}_{3} \mathrm{O}_{3} \mathrm{~F}_{4} \mathrm{OH}\right]$.

\section{Conclusions}

This study showed that the enzyme horseradish peroxidase follows the Michaelis-Menten kinetic model, in the absence and in the presence of the inhibitor $\mathrm{K}_{2}\left[\mathrm{~B}_{3} \mathrm{O}_{3} \mathrm{~F}_{4} \mathrm{OH}\right]$. The presence of the inhibitor $\mathrm{K}_{2}\left[\mathrm{~B}_{3} \mathrm{O}_{3} \mathrm{~F}_{4} \mathrm{OH}\right]$ increases the Michaelis constant $\mathrm{K}_{\mathrm{m}}$ without an impact on the maximum rate $V_{\max }\left(\mathrm{I}_{\max }\right)$ of enzyme reaction. Results suggested that $\mathrm{K}_{2}\left[\mathrm{~B}_{3} \mathrm{O}_{3} \mathrm{~F}_{4} \mathrm{OH}\right]$ is a classical competitive inhibitor. Results from the spectrophotometric and electrochemical methods without guaiacol as a substrate were in agreement, both indicating competitive inhibition. The spectrophotometric method in the presence of varied concentrations of guaiacol showed uncompetitive inhibition which can lead to the conclusion that guaiacol in higher concentrations interferes with the reaction in some way. 
Therefore, the electrochemical method is more suitable for the measurement of kinetic parameters, since there is no need for the electron donor guaiacol to be present.

Acknowledgments: This work has been fully supported by Croatian Science Foundation under Project No. HRZZ-IP-2014-09-6897.

Author Contributions: Jelena Ostojić and Safija Herenda conceived and designed the experiments; Zerina Bešić and Jelena Ostojić performed the experiments; Mladen Miloš analyzed the data; Borivoj Galić synthetized boroxine derivative $\mathrm{K}_{2}\left[\mathrm{~B}_{3} \mathrm{O}_{3} \mathrm{~F}_{4} \mathrm{OH}\right]$. Jelena Ostojić, Safija Herenda, Borivoj Galić and Mladen Miloš contributed to the discussion of results. All authors reviewed the entire manuscript and approved the final version.

Conflicts of Interest: The authors declare no conflict of interest.

\section{References}

1. Islamovic, S.; Galic, B.; Milos, M. A study of the inhibition of catalase by dipotassium trioxohydroxytetrafluorotriborate $\mathrm{K}_{2}\left[\mathrm{~B}_{3} \mathrm{O}_{3} \mathrm{~F}_{4} \mathrm{OH}\right]$. J. Enzym. Inhib. Med. Chem. 2014, 29, 744-748. [CrossRef] [PubMed]

2. Vullo, D.; Milos, M.; Galic, B.; Scozzafava, A.; Supuran, C.T. Dipotassium-trioxohydroxytetrafluorotriborate, $\mathrm{K}_{2}\left[\mathrm{~B}_{3} \mathrm{O}_{3} \mathrm{~F}_{4} \mathrm{OH}\right]$, is a potent inhibitor of human carbonic anhydrases. J. Enzym. Inhib. Med. Chem. 2015, 30, 341-344. [CrossRef] [PubMed]

3. Ostojic, J.; Herenda, S.; Galijasevic, S.; Galic, B.; Milos, M. Inhibition of horseradish peroxidase activity by boroxine derivative, dipotassium-trioxohydroxytetrafluorotriborate $\mathrm{K}_{2}\left[\mathrm{~B}_{3} \mathrm{O}_{3} \mathrm{~F}_{4} \mathrm{OH}\right]$. J. Chem. 2017. [CrossRef]

4. Lei, C.H.; Deng, J.Q. Hydrogen peroxide sensor based on coimmobilized methylene green and horseradish peroxidase in the same montmorillonite-modified bovine serum albumin-glutaraldehyde matrix on a glassy carbon electrode surface. Anal. Chem. 1996, 68, 3344-3349. [CrossRef] [PubMed]

5. Liu, B.H.; Yan, F.; Kong, J.L.; Deng, J.Q. A reagentless amperometric biosensor based on the coimmobilization of horseradish peroxidase and methylene green in a modified zeolite matrix. Anal. Chim. Acta 1999, 386, 31-39. [CrossRef]

6. Ruzgas, T.; Csoregi, E.; Emneus, J.; Gorton, L.; MarkoVarga, G. Peroxidase-modified electrodes: Fundamentals and application. Anal. Chim. Acta 1996, 330, 123-138. [CrossRef]

7. Akkara, J.A.; Senecal, K.J.; Kaplan, D.L. Synthesis and characterization of polymers produced by horseradish peroxidase in dioxane. J. Polym. Sci. Part A: Poly. Chem. 1991, 29, 1561-1574. [CrossRef]

8. Veitch, N.C. Horseradish peroxidase: A modern view of a classic enzyme. Phytochemistry 2004, 65, 249-259. [CrossRef] [PubMed]

9. Aghelan, Z; Shariat, S.Z.S. Partial purification and biochemical characterization of peroxidase from rosemary (Rosmarinus officinalis L.) leaves. Adv. Biomed. Res. 2015, 4, 159. [PubMed]

10. Hirai, H.; Shibata, H.; Kawai, S.; Nishida, T. Role of 1-hydroxybenzotriazole in oxidation by laccase from trametes versicolor. Kinetic analysis of the laccase-1-hydroxybenzotriazole couple. FEMS Microbiol. Lett. 2006, 265, 56-59. [CrossRef] [PubMed]

11. Shetty, P.; Banu, U.; Kedilaya, T.; Patheja, M. Characterization of peroxidase from brassica oleracea gongylodes gives a lead for use of bromocresol purple as a novel substrate for peroxidase assay. J. Biochem. Technol. 2012, 4, 502-507.

12. Tayefi-Nasrabadi, H.; Dehghan, G.; Daeihassani, B.; Movafegi, A.; Samadi, A. Some biochemical properties of guaiacol peroxidases as modified by salt stress in leaves of salt-tolerant and salt-sensitive safflower (Carthamus tinctorius L. cv.) cultivars. Afr. J. Biotechnol. 2011, 10, 751-763.

13. Zatón, A.M.L.; Ochoa de Aspuru, E. Horseradish peroxidase inhibition by thiouracils. FEBS Lett. 1995, 374, 192-194. [CrossRef]

14. Andreu, R.; Ferapontova, E.E.; Gorton, L.; Calvente, J.J. Direct electron transfer kinetics in horseradish peroxidase electrocatalysis. J Phys. Chem. B 2007, 111, 469-477. [CrossRef] [PubMed]

15. Armstrong, F.A.; Hill, H.A.O.; Walton, N.J. Direct electrochemistry of redox proteins. Acc. Chem. Res. 1988, 21, 407-413. [CrossRef]

16. Gu, T.T.; Wang, J.L.; Xia, H.Q.; Wang, S.; Yu, X.T. Direct electrochemistry and electrocatalysis of horseradish peroxidase immobilized in a DNA/chitosan- $\mathrm{Fe}_{3} \mathrm{O}_{4}$ magnetic nanoparticle bio-complex film. Materials 2014, 7, 1069-1083. [CrossRef] 
17. Li, M.G.; Xu, S.D.; Tang, M.; Liu, L.; Gao, F.; Wang, Y.L. Direct electrochemistry of horseradish peroxidase on graphene-modified electrode for electrocatalytic reduction towards $\mathrm{H}_{2} \mathrm{O}_{2}$. Electrochim. Acta 2011, 56, 1144-1149. [CrossRef]

18. Salimi, A.; Sharifi, E.; Noorbakhsh, A.; Soltanian, S. Direct electrochemistry and electrocatalytic activity of catalase immobilized onto electrodeposited nano-scale islands of nickel oxide. Biophys. Chem. 2007, 125, 540-548. [CrossRef] [PubMed]

19. Huang, H.; Hu, N.F.; Zeng, Y.H.; Zhou, G. Electrochemistry and electrocatalysis with heme proteins in chitosan biopolymer films. Anal. Biochem. 2002, 308, 141-151. [CrossRef]

20. Upadhyay, A.K.; Ting, T.W.; Chen, S.M. Amperometric biosensor for hydrogen peroxide based on coimmobilized horseradish peroxidase and methylene green in ormosils matrix with multiwalled carbon nanotubes. Talanta 2009, 79, 38-45. [CrossRef] [PubMed]

21. Zhang, L.; Zhang, Q.; Li, J.H. Direct electrochemistry and electrocatalysis of hemoglobin immobilized in bimodal mesoporous silica and chitosan inorganic-organic hybrid film. Electrochem. Commun. 2007, 9, 1530-1535. [CrossRef]

22. Zhang, Q.A.; Qiao, Y.; Hao, F.; Zhang, L.; Wu, S.Y.; Li, Y.; Li, J.H.; Song, X.M. Fabrication of a biocompatible and conductive platform based on a single-stranded DNA/graphene nanocomposite for direct electrochemistry and electrocatalysis. Chem. Eur. J. 2010, 16, 8133-8139. [CrossRef] [PubMed]

23. Zhao, H.Y.; Sheng, Q.L.; Zheng, J.B. Direct electrochemistry and electrocatalysis of horseradish peroxidase on a gold electrode modified with a polystyrene and multiwalled carbon nanotube composite film. Microchim. Acta 2012, 176, 177-184. [CrossRef]

24. Dunford, H. Horseradish peroxidase: Structure and kinetic properties. Peroxidases Chem. Biol. 1991, 2, 1-24.

25. Li, J.; Tan, S.N.; Ge, H. Silica sol-gel immobilized amperometric biosensor for hydrogen peroxide. Anal. Chim. Acta 1996, 335, 137-145. [CrossRef]

26. Goldstein, L. Microenvironmental effects on enzyme catalysis. Kinetic study of polyanionic and polycationic derivatives of chymotrypsin. Biochemistry 1972, 11, 4072-4084. [CrossRef] [PubMed]

27. Palmer, T. Understanding Enzymes; Ellis Horwood: New York, NY, USA, 1991.

28. Ryss, I.; Slutskaya, M. Report on the platinum sector. Akad Nauk SSSR 1951, 26, 216-218.

29. Chance, B.; Maehly, A. [136] Assay of catalases and peroxidases. Methods Enzymol. 1955, 2, 764-775.

Sample Availability: Samples of the compounds are available from the authors.

(C) 2017 by the authors. Licensee MDPI, Basel, Switzerland. This article is an open access article distributed under the terms and conditions of the Creative Commons Attribution (CC BY) license (http://creativecommons.org/licenses/by/4.0/). 